\title{
Association between pathogens from tracheal aspirate and oral biofilm of patients on mechanical ventilation
}

\section{Luana Carneiro Diniz SOUZA(a) Vanise Barros Rodrigues da MOTA(b) Alícia Valéria dos Santos Zaranza de CARVALHO(b) \\ Rita da Graça Carvalhal Frazão CORRÊA ${ }^{(b)}$ \\ Silvana Amado LIBÉRIO(c) \\ Fernanda Ferreira LOPES(c)}

(a) Universidade Federal do Maranhão - UFMA, Postgraduate Dentistry Program, São Luís, Maranhão, Brazil.

(b) Universidade Federal do Maranhão - UFMA, University Hospital, São Luís, Maranhão, Brazil.

(c) Universidade Federal do Maranhão - UFMA, Department of Dentistry, São Luís, Maranhão, Brazil.

Declaration of Interests: The authors certify that they have no commercial or associative interest that represents a conflict of interest in connection with the manuscript.

Corresponding Author:

Luana Carneiro Diniz Souza

E-mail: luana.dinizz@hotmail.com

https://doi.org/10.1590/1807-3107BOR-2017.vol31.0038

Submitted: Dec 08, 2015

Accepted for publication: Mar 21, 2017

Last revision: Apr 10, 2017

\begin{abstract}
The aim of this study was to detect possible associations between respiratory pathogens from tracheal aspirate and oral biofilm samples in intubated patients in an intensive care unit (ICU), and to identify the most common respiratory pathogens in oral biofilm, particularly in patients that developed ventilator-associated pneumonia (VAP). Two oral biofilm samples were collected from the tongue of intubated patients (at admission and after 48 hours) and analyzed by culture with the Antibiotic Sensitivity Test. The results from the tongue biofilm samples were compared with the tracheal secretions samples. A total of $59.37 \%$ of patients exhibited the same species of pathogens in their tracheal aspirate and oral biofilm, of which 8 (42.1\%) developed VAP, 10 (52.63\%) did not develop pneumonia and one (5.26\%) had aspiration pneumonia. There was a statistically significant association between presence of microorganisms in the tracheal and mouth samples for the following pathogens: Klebsiella pneumoniae, Candida albicans, Pseudomonas aeruginosa, Enterobacter gergoviae, Streptococcus spp and Serratia marcescens ( $\mathrm{p}<0.05)$. Pathogens that are present in tracheal aspirates of intubated patients can be detected in their oral cavity, especially in those who developed VAP or aspiration pneumonia. Thus, the results indicate that an improved oral care in these patients could decrease ICU pneumonia rates.
\end{abstract}

Keywords: Biofilms; Intubation; Pneumonia, Ventilator-Associated; Intensive Care UnitS.

\section{Introduction}

The oral cavity is host to many microorganisms, bearing almost half of the entire microflora of the human body, including the most prevalent species of Streptococcus, Gemella, Eubacterium, Selenomonas, Veillonella, Actinomyces, Atopobium, Rothia, Neisseria, Eikenella, Campylobacter, Porphyromonas, Prevotella, Capnocytophaga, Fusobacterium and Leptotrichia., ${ }^{1,3}$ The oral biofilm is a permanent reservoir of microorganisms and may determine infections in distant body sites. ${ }^{4,5,6}$

Respiratory pathogens are not usually found in the oral microbiota of healthy people, but hospitalized patients are susceptible to oral biofilm colonization by these microorganisms. ${ }^{7}$ Moreover, biofilm components can prevent the penetration of chemotherapeutic agents in the biofilm, making 
those pathogens more resistant to antimicrobial agents and hindering their elimination. ${ }^{8,9}$ In addition, patients at intensive care units (ICUs) frequently exhibit poor oral hygiene, with substantial increase of the oral biofilm. ${ }^{10}$

Ventilator-associated pneumonia (VAP) is an important cause of morbidity and mortality in ICUs. ${ }^{11,12}$ Recent studies have suggested that VAP may be associated with microbial colonization of dental plaque and oropharynx; however, these evaluations were conducted with different methodologies and attained no conclusive results. ${ }^{4,5,6,7}$

A high prevalence of respiratory pathogens, such as Pseudomonas spp. and Acinetobacter ssp., was found in saliva and dental biofilm of hospitalized patients. ${ }^{13,14}$ Significant levels of Staphylococcus aureus, Klebsiella pneumoniae and Enterobacter cloacae have also been found in the dental biofilm of ICU patients..$^{10}$

Due to the diversity of pathogens detected in the oral biofilm of patients with VAP, it is important to investigate which respiratory pathogens can colonize the oral biofilm of intubated patients in ICUs. Thus, the aim of this study was to explore possible associations between respiratory pathogens from tracheal aspirate and oral biofilm in intubated patients in an ICU and to identify the most common respiratory pathogens present in the oral biofilm, particularly in patients that develop VAP.

\section{Methodology}

This research was approved by the Ethics Research Committee of the University Hospital of Federal University of Maranhão - HUUFMA (Protocol No. 251 610). This short-term longitudinal descriptive study used a convenience sample of patients admitted to the General ICU of the "Presidente Dutra" University Hospital (HUUPD). The sample size was defined using the formula for descriptive studies, assuming a $4 \%$ rate of the variable of interest (intubated patients), a sampling error of $5 \%$, a $90 \%$ confidence level, a study design effect of 1.0 and the total of 110 ICU patients, from a period of six months. Thus, the minimum required sample size was 31 intubated patients. Only intubated patients with tracheal secretions were included. Patients with previous episodes of gastric content aspiration, those who underwent thoracic surgery, with chronic obstructive pulmonary disease and carriers of the acquired immune deficiency syndrome virus (AIDS) were excluded ${ }^{7}$. The final sample was 32 patients.

Two lingual biofilm samples were collected from each patient, always in the morning. The first collection was performed at admission, at the same time as the collection of tracheal aspirate samples, and the second collection was performed after exactly 48 hours. Biofilm was collected with a sterile swab and sent for immediate processing for bacterial culture using the antibiotic sensitivity test (AST). Oral sample collections were performed by a single dentist. The collection of tracheal secretion samples was performed using a suction catheter in a sterile bottle, according to the routine of the nursing staff.

The ICU nursing team was trained in accordance with the oral hygiene protocol defined in the Dentistry Department Meeting of the Brazilian Association for Intensive Medicine (Associação de Medicina Intensiva Brasileira, AMIB) of 2011, as follows ${ }^{15}$ :

a. Execution: Nurse technician, nurse, and dentist.

b. Supervision: Dentist.

c. Materials needed: Personal Protection Equipment (PPE), soft infant toothbrush, tongue depressor / tongue scraper, dental floss, $10 \mathrm{~mL}$ of antiseptic mouthwash (cetylpyridinium chloride or essencial oils), suction probe 12-14, oil-based essential fatty acids $/ 5 \%$ dexpanthenol cream, artificial saliva, gauze.

d. Description: 1. Wash hands; 2. Organize necessary materials; 3 . Explain the procedure to the patient; 4 . Position the patient respecting his or her limitations; 5. Put on PPE as needed; 6. In the presence of endotracheal tube: Ensure that the endotracheal tube is appropriately secured, check the cuff inflation pressure (with the help of a Physiotherapist); 7. Perform oropharyngeal aspiration; 8. Moisten the toothbrush in the antiseptic mouthwash and perform oral hygiene with back and forth movements in the tongue, vestibule, cheek mucosa, palate, tooth surfaces (buccal, lingual and occlusal) and gingival; 9. Aspirate saliva and antiseptic from the mouth and oropharynx during and at 
the end of the procedure; 10. Dry with gauze; 11. Perform intra-oral hydration with artificial saliva and perioral lubricants (oil-based essential fatty acids/dexpanthenol cream $5 \%$ - assess dryness of mucous membranes and reduced salivary flow); 12 . Clean and organize the setting: discard gloves, masks and gauze in the contaminated waste bin, wash hands, write a report of the procedure in the clinical file.

e. NOTE 1: Always monitor the mucosa for allergy or sensitivity.

f. NOTE 2: For non-cooperating patients (or with jaw trismus) ask for help from the dentist.

Oral biofilm and tracheal aspirate samples were grown on the following media: MacConkey Agar, Blood Agar, Sabouraud Agar, and BHI broth (Brain Heart Infusion). With the use of a sterile handle, the cultured samples were transferred to an oven $\left(34.5^{\circ} \mathrm{C}\right.$ to $\left.36.5^{\circ} \mathrm{C}\right)$ and kept in aerobic conditions for 24 to 48 hours. After visual bacteria growth, colonies were submitted to Gram staining and viewed under the optical microscope for morphology assessment (gram-positive, gram-negative and yeast).

After, inoculums were prepared by adding microbial colonies to $3 \mathrm{~mL}$ of saline solution, with subsequent adjustment for the McFarland turbidity (0.5-0.63 McF for bacteria and 1.8-2.2 McF for yeast) and taken to the Vitek 2 (bioMérieu) equipment, for microbial identification using identification cards and Advanced Colorimetric ${ }^{\mathrm{TM}}$ technology. ${ }^{16}$

Patients were monitored while in the ICU and progressed as follows: development of VAP, development of aspiration pneumonia, discharge or death. VAP was diagnosed by the medical staff based on the recent diagnostic algorithm for VAP published by the Centers for Disease Control and Prevention / National Health Care Safety Network (CDC / NHSN) in 2012. ${ }^{17}$

The results were tabulated in an Excel spreadsheet (version 2010) and later analyzed by BioEstat statistical software version 5.3 (Optical Digital Technology, Belém, PA, Brazil). Descriptive statistics was initially performed providing absolute and relative frequencies. The Fisher's exact test was used to verify the association of a pathogen in the two different collection sites, oral biofilm and trachea. Statistical significance was set at $5 \%(\mathrm{p}<0.05)$.

\section{Results}

The mean age of the 32 patients was 56 years, and $59.4 \%$ were females and $40.6 \%$ males. The most common cause of hospitalizations was neurological disorders (34.4\%). Of the 32 patients, $40.6 \%$ evolved to VAP and $9.4 \%$ to aspiration pneumonia, while $50 \%$ did not develop pneumonia. Only $37.5 \%$ of patients were discharged and the other $62.5 \%$ died. Of the 13 patients who developed VAP, $53.84 \%$ (seven) died.

Tables 1, 2 and 3 show the distribution of the pathogens identified in the tracheal aspirate and in the two oral samples, according to the patient's pulmonology evolution. There was a decrease in the amount of species detected in the second collection (16 species) compared with the first (20 species). The second oral collection was not performed in four patients because they died within the 48 hourperiod from the first collection.

Table 4 shows the significant associations found between tracheal and oral samples for the following pathogens: Klebsiella pneumoniae, Candida albicans, Pseudomonas aeruginosa, Enterobacter gergoviae, Streptococcus spp and Serratia marcescens. Nineteen of the 32 patients exhibited the same species in tracheal aspirate and oral biofilm, of which 8 developed VAP, accounting for $25 \%$ of the sample. The following pathogens detected in both sites were investigated: Acinetobacter baumannii, Pseudomonas aeruginosa, Enterobacter cloacae, Klebsiella pneumoniae, Enterobacter gergoviae, Candida albicans, Coagulase-negative Staphylococcus spp. and Citrobacter koseri.

Among patients who developed aspiration pneumonia, 33.3\% harbored Streptococcus spp. The most frequent pathogen in patients that did not progress to pneumonia was Candida albicans, found in the tracheal aspirate $(25 \%)$, and in both oral collections ( $25 \%$ in the first and $37.5 \%$ in the second collection).

\section{Discussion}

In recent years, studies on VAP caused by microorganisms have focused on the oropharynx and the mouth as pathogens' sources. ${ }^{18}$ In this study, respiratory pathogens, such as Acinetobacter baumannii, Klebsiella pneumoniae and Pseudomonas aeruginosa, 
Table 1. Distribution of pathogens identified in the tracheal aspirate of mechanically ventilated patients in the adult intensive care unit according to the pulmonology evolution of the patient.

\begin{tabular}{|c|c|c|c|c|c|c|}
\hline \multirow[t]{2}{*}{ Pathogen in tracheal aspirate } & \multicolumn{2}{|c|}{ Without pneumonia } & \multicolumn{2}{|c|}{$\begin{array}{l}\text { Ventilator associated } \\
\text { pneumonia }\end{array}$} & \multicolumn{2}{|c|}{ Aspiration pneumonio } \\
\hline & $\mathrm{n}=16$ & $\%$ & $n=13$ & $\%$ & $n=3$ & $\%$ \\
\hline 1. Klebsiella pneumoniae & 1 & 6.25 & 2 & 15.4 & 1 & 33.33 \\
\hline 2. Candida albicans & 4 & 25 & 1 & 7.7 & 0 & - \\
\hline 3.Staphylococcus epidermidis & 1 & 6.25 & 2 & 15.4 & 0 & - \\
\hline 4. Enterococcus faecalis & 0 & - & 1 & 7.7 & 0 & - \\
\hline 5. Pseudomonas aeruginosa & 2 & 12.5 & 2 & 15.4 & 0 & - \\
\hline 6. Enterobacter gergoviae & 0 & - & 1 & - & 0 & - \\
\hline 7.Staphylococcus haemolyticus & 1 & 6.25 & 0 & - & 0 & - \\
\hline 8.Streptococcus spp & 1 & 6.25 & 1 & 7.7 & 1 & 33.33 \\
\hline 9.Acinetobacter baumannii & 1 & 6.25 & 4 & 30.77 & 0 & - \\
\hline 10.Serratia marcescens & 1 & 6.25 & 0 & - & 0 & - \\
\hline 11.Candida tropicalis & 1 & 6.25 & 0 & - & 0 & - \\
\hline 12. Coagulase-negative Staphylococcus & 2 & 12.5 & 2 & 15.4 & 0 & - \\
\hline 13.Stenotrophomonas maltophilia & 1 & 6.25 & 1 & 7.7 & 0 & - \\
\hline 14.Burkholderia cepacia & 1 & 6.25 & 0 & - & 0 & - \\
\hline 15.Enterobacter cloacae & 0 & - & 2 & $15.4 \%$ & 0 & - \\
\hline 16. Escherichia coli & 0 & - & 0 & - & 1 & 33.33 \\
\hline 17.Staphylococcus aureus & 1 & 6.25 & 0 & - & 0 & - \\
\hline 18.Elizabethkingia meningoseptica & 0 & - & 1 & 7.7 & 0 & - \\
\hline 19. Citrobacter koseri & 0 & - & 1 & 7.7 & 0 & - \\
\hline Total pathogens & 18 & - & 21 & - & 3 & - \\
\hline
\end{tabular}

Source: University Hospital of UFMA (April-September, 2013).

Table 2. Distribution of pathogens identified in the first (at admission) oral collection of patients on mechanical ventilation in the adult intensive care unit according to the pulmonology evolution of the patient.

\begin{tabular}{|c|c|c|c|c|c|c|}
\hline \multirow{2}{*}{$\begin{array}{l}\text { Pathogen } \\
\text { First oral collection }\end{array}$} & \multicolumn{2}{|c|}{ Without pneumonia } & \multicolumn{2}{|c|}{$\begin{array}{c}\text { Ventilator associated } \\
\text { pneumonia }\end{array}$} & \multicolumn{2}{|c|}{ Aspiration pneumoni } \\
\hline & $n=16$ & $\%$ & $\mathrm{n}=13$ & $\%$ & $\mathrm{n}=3$ & $\%$ \\
\hline 1.Candida albicans & 4 & 25 & 3 & 23.08 & 1 & 33.33 \\
\hline 2.Staphylococcus epidermidis & 4 & 25 & 2 & 15.4 & 0 & - \\
\hline 3. Enterococcus faecalis & 1 & 6.25 & 1 & 7.7 & 0 & - \\
\hline 4.Pseudomonas aeruginosa & 3 & 18.75 & 4 & 30.8 & 0 & - \\
\hline 5.Enterobacter gergoviae & 0 & - & 1 & 7.7 & 0 & - \\
\hline 6.Staphylococcus haemolyticus & 0 & - & 1 & 7.7 & 0 & - \\
\hline 7.Streptococcus spp & 3 & 18.75 & 2 & 15.4 & 2 & 66.66 \\
\hline 8.Acinetobacter baumannii & 2 & 12.5 & 3 & 23.08 & 0 & - \\
\hline 9.Serratia marcescens & 1 & 6.25 & 0 & - & 0 & - \\
\hline 10. Candida tropicalis & 2 & 12.5 & 1 & 7.7 & 0 & - \\
\hline 11. Coagulase-negative Staphylococcus & 1 & 6.25 & 1 & 7.7 & 1 & 33.33 \\
\hline 12. Enterobacter aerogenes & 0 & - & 1 & 7.7 & 0 & - \\
\hline 13.Burkholderia cepacia & 2 & 12.5 & 0 & - & 0 & - \\
\hline 14.Enterobacter cloacae & 0 & - & 1 & 7.7 & 0 & - \\
\hline 15.Stephanoascus ciferri & 1 & 6.25 & 0 & - & 0 & - \\
\hline 16.Staphylococcus aureus & 2 & 12.5 & 1 & 7.7 & 1 & 33.33 \\
\hline 17.Pseudomonas fluorescens & 1 & 6.25 & 0 & - & 0 & - \\
\hline 18. Citrobacter koseri & 0 & - & 1 & 7.7 & 0 & - \\
\hline 19.Steptococcus pneumoniae & 1 & 6.25 & 0 & - & 0 & - \\
\hline 20.Klebsiella pneumoniae & 1 & 6.25 & 3 & 23.08 & 0 & - \\
\hline
\end{tabular}

Source: University Hospital of UFMA (April-September, 2013). 
Table 3. Distribution of pathogens identified in the second (48 h) oral collection of patients on mechanical ventilation in the adult intensive care unit according to the pulmonology evolution of the patient.

\begin{tabular}{|c|c|c|c|c|c|c|}
\hline \multirow{2}{*}{$\begin{array}{l}\text { Pathogen } \\
\text { Second oral collection ( } 48 \text { hours after admission) }\end{array}$} & \multicolumn{2}{|c|}{ Without pneumonia } & \multicolumn{2}{|c|}{$\begin{array}{c}\text { Ventilator associated } \\
\text { pneumonia }\end{array}$} & \multicolumn{2}{|c|}{ Aspiration pneumonio } \\
\hline & $n=13$ & $\%$ & $n=13$ & $\%$ & $\mathrm{n}=2$ & $\%$ \\
\hline 1.Klebsiella pneumoniae & 2 & 12.5 & 4 & 30.8 & 0 & - \\
\hline 2. Candida albicans & 6 & 37.5 & 4 & 30.8 & 1 & 33.33 \\
\hline 3.Staphylococcus epidermidis & 4 & 25 & 2 & 15.4 & 0 & - \\
\hline 4. Enterococcus faecalis & 1 & 6.25 & 1 & 7.7 & 0 & - \\
\hline 5.Pseudomonas aeruginosa & 3 & 18.75 & 7 & 53.8 & 0 & - \\
\hline 6. Enterobacter gergoviae & 0 & - & 1 & 7.7 & 0 & - \\
\hline 7.Staphylococcus haemolyticus & 1 & 6.25 & 2 & 15.4 & 0 & - \\
\hline 8.Streptococcus spp & 1 & 6.25 & 0 & - & 1 & 33.33 \\
\hline 9.Acinetobacter baumannii & 2 & 12.5 & 2 & 15.4 & 1 & 33.33 \\
\hline 10.Serratia marcescens & 1 & 6.25 & 0 & - & 0 & - \\
\hline 11. Candida tropicalis & 3 & 18.75 & 0 & - & 0 & - \\
\hline 12. Coagulase-negative Staphylococcus & 1 & 6.25 & 1 & 7.7 & 0 & - \\
\hline 13.Enterobacter aerogenes & 1 & 6.25 & 1 & 7.7 & 0 & - \\
\hline 14. Enterobacter cloacae & 0 & - & 1 & 7.7 & 0 & - \\
\hline 15.Stephanoascus ciferri & 1 & 6.25 & 0 & - & 0 & - \\
\hline 16.Staphylococcus aureus & 1 & 6.25 & 0 & - & 0 & - \\
\hline
\end{tabular}

Source: University Hospital of UFMA (April-September, 2013).

were detected in the oral cavity of mechanically ventilated patients. This result confirms that patients in ICU may present a significant level of respiratory pathogens in their microbiota. ${ }^{10}$

Acinetobacter baumannii is the most frequently isolated bacterial species in tracheal secretion cultures of patients with $\mathrm{VAP}^{19}$. In the present study, a high proportion of patients who developed VAP presented Acinetobacter baumannii (30.77\%) in the tracheal aspirate. However, Barbier et $\mathrm{al}^{20}$ found that the pathogens most often associated with VAP were Staphylococcus aureus, Pseudomonas aeruginosa and Enterobacteriaceae. In our study, Pseudomonas aeruginosa and Enterobacter cloacae were also detected in patients who developed VAP, but less frequently than Acinetobacter baumannii.

At the time of hospital admission, the presence of Acinetobacter baumannii, Pseudomonas aeruginosa, Klebsiella pneumoniae and Enterobacter cloacae was observed in the oral biofilm of patients. After 48 hours, $25 \%$ of the patients developed VAP, exhibiting the same pathogens in their tracheal aspirate. These pathogens are reported in other studies as the most frequently associated with VAP. ${ }^{19,20}$ However, other pathogens such as Citrobacter koseri, Proteus mirabilis, Pseudomonas aeruginosa and Pseudomonas fluorescence have also been detected in both oral and tracheal samples of intubated or tracheotomy patients at ICUs ${ }^{21}$, indicating their important role in the pathogenesis of VAP. ${ }^{22}$

Tracheal aspirate collection is routinely performed in patients with clinical signs of infection at admission before starting antibiotic therapy. ${ }^{23,24}$ An association of Klebsiella pneumoniae and Pseudomonas aeruginosa was found between tracheal aspirate and oral biofilm from the first collection only. One explanation for these findings is that the antibiotics chosen at the patient's admission, which were specific for those pathogens due to their association with VAP etiology, could have eliminated them from the oral cavity within the 48-hour interval from the first to the second collection ${ }^{19,20}$. 
Table 4. Distribution of study participants according to the presence of the same species of microorganisms in both oral collections, as well as tracheal aspirate of mechanically ventilated patients in the adult intensive care unit.

\begin{tabular}{|c|c|c|c|c|c|}
\hline \multirow{3}{*}{ Pathogen in oral sample } & \multicolumn{4}{|c|}{ Tracheal sample } & \multirow{3}{*}{$\mathrm{p}$-value } \\
\hline & \multicolumn{2}{|c|}{ Present } & \multicolumn{2}{|c|}{ Absent } & \\
\hline & $\mathrm{n}$ & $\%$ & $\mathrm{n}$ & $\%$ & \\
\hline Klebsiella pneumoniae (1 st. collection) & & & & & $0.01^{*}$ \\
\hline Present & 4 & 50.0 & 4 & 50.0 & \\
\hline Absent & 2 & 7.2 & 26 & 92.8 & \\
\hline Klebsiella pneumoniae (2nd. collection) & & & & & 0.57 \\
\hline Present & 0 & 0 & 6 & -100 & \\
\hline Absent & 3 & 15.8 & 19 & 84.2 & \\
\hline Candida albicans (1 st. collection) & & & & & $<0.01^{*}$ \\
\hline Present & 5 & 62.5 & 3 & 37.5 & \\
\hline Absent & 0 & 0 & 24 & -100 & \\
\hline Candida albicans (2nd collection) & & & & & $0.01^{*}$ \\
\hline Present & 4 & 36.4 & 7 & 63.6 & \\
\hline Absent & 0 & 0 & 17 & -100 & \\
\hline Pseudomonas aeruginosa (1 st. collection) & & & & & $0.02^{*}$ \\
\hline Present & 3 & 14.2 & 4 & 42.8) & \\
\hline Absent & 1 & 4.0 & 24 & 96.0 & \\
\hline Pseudomonas aeruginosa (2nd. collection) & & & & & 0.11 \\
\hline Present & 3 & 30.0 & 7 & 70.0 & \\
\hline Absent & 1 & 5.6 & 17 & 94.4 & \\
\hline Enterobacter gergoviae (1 st. collection) & & & & & $0.03^{*}$ \\
\hline Present & 1 & -100 & 0 & 0 & \\
\hline Absent & 0 & 0 & 31 & -100 & \\
\hline Enterobacter gergoviae (2nd. collection) & & & & & $0.03^{*}$ \\
\hline Present & 1 & -100 & 0 & 0 & \\
\hline Absent & 0 & 0 & 27 & -100 & \\
\hline Streptococcus spp (1 st. collection) & & & & & 0.35 \\
\hline Present & 2 & 28.6 & 5 & 71.4 & \\
\hline Absent & 1 & 4.0 & 24 & 96.0 & \\
\hline Streptococcus spp (2nd. collection) & & & & & $<0.01^{*}$ \\
\hline Present & 2 & -100 & 0 & 0 & \\
\hline Absent & 1 & 3.8 & 25 & 96.2 & \\
\hline Serratia marcescens (1 st. collection) & & & & & $0.03^{*}$ \\
\hline Present & 1 & -100 & 0 & 0 & \\
\hline Absent & 0 & 0 & 31 & -100 & \\
\hline Serratia marcescens (2nd. collection) & & & & & $0.03^{*}$ \\
\hline Present & 1 & -100 & 0 & 0 & \\
\hline Absent & 0 & 0 & 27 & -100 & \\
\hline
\end{tabular}

Source: University Hospital of UFMA (April-September, 2013).

Fisher's exact test. *Statistically significant difference $(p<0.05)$.

A relevant aspect of this study was the collection of oral samples in two stages: on admission and after 48 hours. Thus, the change in the oral flora between the two time-points could be evaluated, following the course of the disease. Although a quantitative analysis of individual species was not done, a small decrease in the number of species was observed from the first (20 species) to the second collection (16 species). Some studies have shown a quantitative increase of pathogens that colonize the oral biofilm of patients in ICU with time. ${ }^{10,25}$ However, the patients of this study had oral hygiene performed by trained nurse 
technicians under the supervision of a dentist, which might have decreased the reservoir of respiratory pathogens in the dental plaque between sample collections. $^{22}$

Although the ICU nursing staff had been calibrated for the oral hygiene of intubated patients, the absence of oral hygiene products that should be supplied by the hospital, such as chlorhexidine, may have contributed for the high number of pathogens found in the collected samples. The use of chlorhexidine in oral hygiene significantly decreases the oropharyngeal colonization with gram-negative and gram-positive microorganisms and the incidence of VAP. ${ }^{26,27,28,29,30,3-32}$ Moreover, in our study, oral hygiene (mechanical removal of biofilm) was done twice a day at most, which may partly explain the high rate of respiratory pathogens found in the oral biofilm of patients and the high prevalence of VAP (40.6\%) in the period of data collection. The chemical control of oral pathogens by $0.12 \%$ chlorhexidine seems to be more effective in preventing VAP than the mechanical removal by toothbrushing. ${ }^{33}$

Fifty-nine percent of patients exhibited the same species of pathogens in their tracheal aspirate and oral biofilm, of which $42.1 \%$ evolved to VAP. VAP is an infection caused predominantly by aerobic microorganisms, with an unclear role of anaerobic pathogens. ${ }^{34}$ VAP is a nosocomial infection that causes significant morbidity and mortality in ICUs and prolongs hospitalization. ${ }^{22}$

Candida spp rarely lead to pneumonia. Its isolation in respiratory material is usually due to the colonization, until proven otherwise. ${ }^{35}$ Candida colonization of the respiratory tract occurs in up to $80 \%$ of critical ICU patients, ${ }^{36,37}$ unlike invasive candidiasis, which is less than $10 \% .38,39$ Patients who did not progress to pneumonia exhibited high Candida albicans concentration in the tracheal aspirate, as well as in the oral biofilm, especially in the second sample collection. However, in another study, Candida albicans was the most frequent microorganism detected in the tracheal aspirate of patients diagnosed with VAP after cardiac surgery. ${ }^{40}$ Thus, it is necessary to carefully analyze the hypothesis that fungi are the 2nd most common etiological agents of VAP after gram-negative non-fermenting bacilli. ${ }^{40}$ In our study, there was only 1 patient $(7.7 \%)$ positive for Candida albicans among the 13 patients who developed VAP, suggesting that the widespread use of broad-spectrum antibiotics can lead to fungal emergence in patients with VAP. ${ }^{40}$ This emphasizes the importance of having guidelines for Candida colonization and invasive candidiasis assessment and thus establishing early antifungal treatment, according to the diagnosis. ${ }^{41}$

The incidence of aspiration pneumonia has been associated with dysphagia and with oral colonization by respiratory pathogens. Effective prevention for this pathology is achieved with the elimination of respiratory pathogens through oral hygiene and improvement of oral functions such as swallowing. ${ }^{42}$ In the present study, Streptococcus spp was observed in the oral biofilm and tracheal aspirate of patients with aspiration pneumonia, which confirms the theory that oral bacteria that colonize the oropharynx can be aspirated into the lower respiratory tract, particularly in individuals with high risk of infection such as hospitalized patients. Nevertheless, there is no consensus in the literature regarding the hypothesis that oral bacteria may contribute to the etiology of respiratory diseases. ${ }^{43}$

\section{Conclusion}

Based on the follow up of patients on mechanical ventilation in an adult ICU, this study reported on the disease evolution according to the bacteria detected in the respiratory tract and oral biofilm, in which Acinetobacter baumannii was the most common respiratory pathogen in tracheal aspirate, and Pseudomonas aeruginosa was the most common in both oral sample collections. Pathogens present in tracheal aspirates of intubated patients can be detected also in the oral cavity of these patients, especially of those who developed VAP or aspiration pneumonia. Thus, it is concluded that the oral cavity can be a reservoir of respiratory pathogens in patients under mechanical ventilation. In order to reduce rates of ICU pneumonia, a greater attention to oral hygiene and care of ICU patients is recommended. 


\section{References}

1. Aas JA, Paster BJ, Stokes LN, Olsen I, Dewhirst FE. Defining the normal bacterial flora of the oral cavity. J Clin Microbiol. 2005; 43(11):5721-32. https://doi.org/10.1128/JCM.43.11.5721-5732.2005

2. Dewhirst FE, Chen T, Izard J, Paster BJ, Tanner AC, Yu WH et al. The human oral microbiome. J Bacteriol. 2010;192(19):5002-17. https://doi.org/10.1128/JB.00542-10

3. Palmer RJ Jr. Composition and development of oral bacterial communities. Periodontol 2000. 2014;64(1):1-24. https://doi.org/10.1111/j.1600-0757.2012.00453.x

4. Scannapieco FA, Rethman MP. The relationship between periodontal diseases and respiratory diseases. Dent Today. 2003;22(8):79-83.

5. El-Solh AA, Pietrantoni C, Bhat A, Okada M, Zambon J, Aquilina $A$ et al. Colonization of dental plaques: a reservoir of respiratory pathogens for hospital-acquired pneumonia in institutionalized elders. Chest. 2004;126(5):1575-82. https://doi.org/10.1016/S0012-3692(15)31374-X

6. Amaral SM, Cortês AQ, Pires FR. Pneumonia nosocomial: importância do microambiente oral. J Bras Pneumol. 2009;35(11):1116-24. http://dx.doi.org/10.1590/S1806-37132009001100010

7. Oliveira LBS, Carneiro PPM, Fischer RG, Tinoco BEM. A presença de patógenos respiratórios no biofilme bucal de pacientes com pneumonia nosocomial. Rev Bras Ter Intensivo. 2007;19(4):428-33. 07X. http://dx.doi.org/10.1590/S0103-507X2007000400004

8. Smith AJ, Jackson MS, Bagg J. The ecology of Staphylococcus species in the oral cavity. J Med Microbiol. 2001;50(11):940-6. https://doi.org/10.1099/0022-1317-50-11-940

9. Huang R, Li M, Gregory RL. Bacterial interactions in dental biofilm. Virulence. 2011;2(5):435-44. https://doi.org/10.4161/viru.2.5.16140

10. Sachder M, Ready D, Brealey D, Ryu J, Bercades G, Nagle J et al. Changes in dental plaque following hospitalisation in a critical care unit: an observational study. Critical Care. 2013;17(5R189):R189. https://doi.org/10.1186/ccl2878

11. Hingston CD, Cole JM, Hingston EJ, Frost PJ, Wise MP. Oral hygiene and nosocomial pneumonia in critically ill patients. Chest Journal. 2010;137(1):237-8. https://doi.org/10.1378/chest.09-1319

12. DeKeyser Ganz F, Fink NF, Raanan O, Asher M, Bruttin M, Nun MB et al. ICU nurses' oral-care practices and the current best evidence. J Nurs Scholarsh. 2009;41(2):132-8. https://doi.org/10.1111/j.1547-5069.2009.01264.x

13. Zuanazzi D, Souto R, Mattos MB, Zuanazzi MR, Tura BR, Sansone $C$ et al. Prevalence of potential bacterial respiratory pathogens in the oral cavity of hospitalised individuals. Arch Oral Biol. 2010;55(1):21-8. https://doi.org/10.1016/i.archoralbio.2009.10.005

14. Paju S, Scannapieco FA. Oral biofilms, periodontitis, and pulmonary infections. Oral Dis. 2007;13(6):508-12. https://doi.org/10.1111/j.1601-0825.2007.01410a.x

15. Associação de Medicina Intensiva Brasileira - AMIB. Procedimento operacional padrão: higiene bucal (HB) em UTI (adulto). São Paulo: Associação de Medicina Intensiva Brasileira; 2014.

16. Clinical Laboratory and Standards Institute - CLSI. Performance standards for antimicrobial susceptibility testing; twnty-fifth informational supplement. Wayne: Clinical Laboratory and Standards Institute; 2013.

17. Centers for Disease Control and Prevention - CDC. Ventilator-Associated Event (VAE) surveillance for adults special edition. Atlanta: Centers for Disease Control and Prevention; 2012.

18. Sands KM, Wilson MJ, Lewis MA, Wise MP, Palmer N, Hayes AJ et al. Respiratory pathogen colonization of dental plaque, the lower airways, and endotracheal tube biofilms during mechanical ventilation. J Crit Care. 2017;37:30-7. https://doi.org/10.1016/i.jcrc.2016.07.019

19. Medell M, Hart M, Duquesne A, Espinosa F, Valdés R. Nosocomial ventilator-associated pneumonia in cuban intensive care units: bacterial species and antibiotic resistance. MEDICC Rev. 2013;15(2):26-9.

20. Barbier F, Andremont A, Wolff M, Bouadma L. Hospital-acquired pneumonia and ventilator-associated pneumonia: recent advances in epidemiology and management. Curr Opin Pulm Med. 2013;19(3):216-28. https://doi.org/10.1097/MCP.0b013e32835f27be

21. Santos PSS, Mariano M, Kallas MS, Vilela MCN. Impacto da remoção de biofilme lingual em pacientes sob ventilação mecânica. Rev Brás Ter Intensiva. 2013;25(1):44-8. http://dx.doi.org/10.1590/S0103-507X2013000100009

22. Karatas M, Saylan S, Kostakoglu U, Yilmaz G. An assessment of ventilator-associated pneumonias and risk factors identified in the Intensive Care Unit. Pak J Med Sci. 2016;32(4):817-22. http://dx.doi.org/10.12669/pims.324.10381.

23. Reinhart K, Brunkhorst FM, Bone HG, Bardutzky J, Dempfle CE, Forst $\mathrm{H}$ et al. Prevention, diagnosis, therapy and follow-up care of sepsis: 1 st revision of S-2k Guidelines of the German Sepsis Society (Deutsche Sepsis-Gesellschafte.V. (DSG)) and the German Interdisciplinary Association of Intensive Care and Emergency Medicine (Deutsche InterdisziplinäreVereinigungfürlntensiv- und Notfallmedizin (DIVI)). German Med Sci. 2010;8:1-43.

24. Dellinger RP, Levy MM, Rhodes A, Annane D, Gerlach H, Opal SM et al. Surviving Sepsis Campaign: International guidelines for management of severe sepsis and septic shock. Intensive Care Med. 2013;39(2):165-228. https://doi.org/10.1007/s00134-012-2769-8 
25. Munro CL, Grap MJ. Oral health and care in the intensive care unit: state of the science. Am J Crit Care. 2004;13(1):25-33.

26. Koeman M, Ven AJ, Hak E, Joore HC, Kaasjager K, Smet $A G$ et al. Oral decontamination with chlorhexidine reduces the incidence of ventilator-associated pneumonia. Am J Respir Crit Care Med. 2006;173(12):1348-55. https://doi.org/10.1164/rccm.200505-8200C

27. Chlebicki MP, Safdar N. Topical chlorhexidine for prevention of ventilator-associated pneumonia: a meta-analysis. Crit Care Medicine. 2007;35(2):595-602. https://doi.org/10.1097/01.CCM.0000253395.70708.AC

28. Chan EY, Ruest A, Meade MO, Cook DJ. Oral decontamination for prevention of pneumonia in mechanically ventilated adults: systematic review and meta-analysis. BMJ. 2007;334(7599):889. https://doi.org/10.1136/bmi.39136.528160.BE

29. Munro CL, Grap MJ, Jones DJ, McClish DK, Sessler CN. Chlorhexidine, toothbrushing, and preventing ventilator-associated pneumonia in critically ill adults. Am J Crit Care.2009;18(5):428-37. https://doi.org/10.4037/ajcc2009792

30. Oliveira MS, Borges AH, Mattos FZ, Semenoff TA, Segundo AS, Tonetto MR et al. Evaluation of different methods for removing oral biofilm in patients admitted to the intensive care unit. J Int Oral Health. 2014;6(3):61-4.

31. Nicolosi LN, Carmen Rubio M, Martinez CD, González NN, Cruz ME. Effect of oral hygiene and $0.12 \%$ chlorhexidine gluconate oral rinse in preventing ventilator-associated pneumonia after cardiovascular surgery. Respir Care. 2014;59(4):504-9. https://doi.org/10.4187/respcare.02666

32. Liao YM, Tsai JR, Chou FH. The effectiveness of an oral health care program for preventing ventilator-associated pneumonia. Nurs Crit Care. 2015;20(2):89-97. https://doi.org/10.1111/nicc.12037

33. Vilela MC, Ferreira GZ, Santos PS, Rezende NP. Oral care and nosocomial pneumonia: a systematic review. Einstein (São Paulo). 2015;13(2):290-6. https://doi.org/10.1590/S1679-45082015RW2980

34. Park DR. The microbiology of ventilator-associated pneumonia. Respir Care. 2005;50(6):742-63.
35. Sociedade Paulista de Infectologia. Diretrizes sobre pneumonia associada a ventilação mecânica (PAV). São Paulo: Office; 2006.

36. Vincent JL, Rello J, Marshall J, Silva E, Anzueto A, Martin CD et al. International study of the prevalence and outcomes of infection in intensive care units. JAMA. 2009;302(21):2323-9. https://doi.org/10.1001/jama.2009.1754

37. Pfaller M, Neofytos D, Diekema D, Azie N, Meier-Kriesche HU, Quan SP et al. Epidemiology and outcomes of candidemia in 3648 patients: data from the Prospective Antifungal Therapy (PATH Alliance ${ }^{\circledR}$ ) registry, 2004-2008. Diagn Microbiol Infect Dis. 2012;74(4):323-31. https://doi.org/10.1016/i.diagmicrobio.2012.10.003

38. Guery BP, Arendrup MC, Auzinger G, Azoulay E, Borges Sá M, Johnson EM et al. Management of invasive candidiasis and candidemia in adult non-neutropenic intensive care unit patients: part I. Epidemiology and diagnosis. Intensive Care Med. 2009;35(1):55-62. https://doi.org/10.1007/s00134-008-1338-7

39. Kett DH, Azoulay E, Echeverria PM, Vincent JL, Extended Prevalence of Infection in ICU Study (EPIC II) Group of Investigators. Candida bloodstream infections in intensive care units: analysis of the extended prevalence of infection in intensive care unit study. Crit Care Med. 2011;39(4):665-70. https://doi.org/10.1097/CCM.0b013e318206clca

40. Serban RI, Dan M, Pânzaru CV, Anghel D, Dăscălescu D, Ciucu L et al. [Fungi as emergent etiologic agents in ventilator-associated pneumonia after cardiac surgery]. Rev Med Chir Soc Med Nat lasi. 2010;114(4):1077-82. Romarian.

41. Bruyère R, Quenot JP, Prin S, Dalle F, Vigneron C, Aho $S$, et al. Empirical antifungal therapy with an echinocandin in critically-ill patients: prospective evaluation of a pragmatic Candida score-based strategy in one medical ICU. BMC Infect Dis. 2014;14(1):385. https://doi.org/10.1186/1471-2334-14-385

42. Tada A, Miura H. Prevention of aspiration pneumonia (AP) with oral care. Arch Gerontol Geriatr. 2012;55(1):16-21. https://doi.org/10.1016/i.archger.2011.06.029

43. Gomes-Filho IS, Passos JS, Cruz SS. Respiratory disease and the role of oral bacteria. J Oral Microbiol. 2010;2(5811):1-6. https://doi.org/10.3402/jom.v2i0.5811 